\title{
AMERICAN DISCOURSES OF THE DIGITAL DIVIDE AND ECONOMIC DEVELOPMENT: A Sisyphean ${ }^{1}$ Order to Catch Up?
}

\author{
Leslie Tu \\ Lynette Kvasny \\ Pennsylvania State University \\ University Park, PA U.S.A.
}

\begin{abstract}
Discourses about technology and its role in development have been constant themes within IFIP Working Group 8.2 (see the Barcelona proceedings-Wynn et al. 2002). In this paper, we examine how strands of discourse-institutionalized ways of thinking and speaking-shape debate about the digital divide and urban poverty in America. As research is widely esteemed as a wellspring of new ideas, we are especially interested in how discourses inform scholarly inquiry into urgent social problems. As information and communication technologies (ICTs) are increasingly hailed as drivers of industry and commerce, we believe that it will be instructive to examine economic development discourse, which strongly informs the case for bridging the digital divide.

First, using Fairclough's three-level framework for critical discourse analysis (CDA), we reveal that the discursive hegemony of economic development alarmingly constrains approaches to urban revitalization. Linking economic development to the digital divide, we show how the ongoing evolution of ICTs has become tightly linked to economic development. Both are discourses of equality in which those who lack money and technology are
\end{abstract}

'In Greek mythology, Sisyphus was a bold, crafty king of Corinth who angered Zeus by speaking unfavorably of him. The king of the gods became bent on his death, and sent his reaper to haul Sisyphus off to Tartarus. Twice, shrewd Sisyphus cheated death and returned among the living, until at last Zeus devised a special punishment for his impiety: In Tartarus, Sisyphus would have to roll an enormous rock up a hill; just as he would reach the summit, the rock would roll back down, and the laborious task would begin again. The insolent king was condemned to this toil for all eternity.

Please use the following format when citing this chapter:

Tu, L., and Kvasny, L., 2006, in IFIP International Federation for Information Processing, Volume 208, Social Inclusion: Societal and Organizational Implications for Information Systems, eds. Trauth, E., Howcroft, D., Butler, T., Fitzgerald, B., DeGross, J., (Boston: Springer), pp. 51-65. 
cast as needy problem sectors that will be left behind, failing to reap a host of benefits. Hence, there is an urgent call for these "have-nots" to catch up to models of prosperity embodied by the wealthy or technology savvy. We find fault with this discourse because it narrowly privileges money and technology, and raises alarm at their mere absence, while obscuring substantive needshunger, homelessness, ill health-of actual consequence. We propose that, in order truly to realize the potential of ICT, we must first reinvent discoursediscarding the mantra of catching up-and set in motion efforts to address self-determined needs, supported by ICT.

\section{INTRODUCTION}

Information and communication technologies (ICTs) are rapidly assuming importance in myriad domains, especially those concerned with economic advancement. Well endowed sectors are overwhelmingly optimistic, touting novel opportunities for business in a global, digital economy.

But, as vast resources are readily committed to improving information tools for the technology savvy, underserved Americans ${ }^{2}$ seem only to be gaining from these developments a new claim to exclusion. Long before ICT had acquired mainstream prevalence, the complex problems of poverty and social exclusion had even the most astute scholars and policymakers at a loss. Today, we remain far from having resolved the grave needs of hunger, homelessness, educational deficits, and crime that hold basic life chances beyond the reach of many inner city residents. The rhetoric that celebrates a burgeoning information economy and revolutionary technological advances rings hollow in economically depressed neighborhoods where local residents must contend with more immediate obstacles such as social marginalization and financial hardship.

Because economic development has become the default remedy for poverty, and since ICTs are seen as a cornerstone of economic development (e.g., Thompson 2002; White House 2004), the digital divide has attracted intense interest. The digital divide projects a new form of inequality, whereby society is split between "haves," who enjoy access to ICTs and their benefits, and "have-nots," who somehow lack the means or desire to use them. Increasingly, the discourse that calls for bridging the technological gap draws urgency from the broader debate concerning economic development. Nonusers of ICT, experts commonly warn, risk exclusion from the new economy and other emerging opportunities introduced by these tools.

In what follows, we offer our understanding of discourse and how influential social agents and institutions employ discursive practices designed to garner the complicity of others. We then take up economic development, a prominent discourse that rarely meets

${ }^{2}$ By historically underserved Americans, we mean those who have systematically been marginalized in a host of spheres that affect their life chances. This includes Americans with disabilities, low incomes, and limited formal education. It also includes immigrants, racial and ethnic minorities, as well as inner city and urban communities. For decades, these are the people who have been disadvantaged in a host of domains that largely determine social mobility and inclusion. 
opposition as a necessary, even laudable strategy for alleviating urban poverty. Using Fairclough's three-level framework for critical discourse analysis (CDA), and guided by Thompson's (2002) critical study of ICT and third world development discourse, we examine the ideas and assumptions underlying academic inquiry into economic distress in American inner cities. Noting how dominant discourses pervade even the province of scholars - long regarded as free-thinking innovators - we then ask how this very hegemony of economic development is steering campaigns for bridging the digital divide. In our analysis we adopt a critical stance, troubled by (1) a dominant economic development discourse that privileges money while failing to inform substantive improvement and (2) what we observe as economic development both shaping and being co-opted to validate the case for bridging the digital divide. We are skeptical of this association because such a bridge is narrowly constructed, removed from substantive needs, and, without a shift in thinking, never to see completion. Like Sisyphus-who time and again seemed to be reaching the end of his toil, only to have the rock roll down and his labor begin all over - as long as the poor are locked into a discourse of catching up, their race will never end. We conclude by offering alternative ways to conceptualize the digital divide discourse - alternatives that encourage the underserved to express their own experiences, leverage their cultural competencies and social networks, and ultimately use ICT creatively to fulfill self-determined needs.

\section{DEFINING DISCOURSE}

Popular understandings about the digital divide and economic development are profoundly shaped by their proponents' highly selective language. Foucault describes discourse as "a sets of statements that make up a language for discussing a certain topic at some historical moment" (Foucault cited in Kvasny and Sawyer 2002). It constrains the way in which we can meaningfully reason and talk about a topic and, often, assumptions imposed by a discourse are hardly contested or interrogated - with the result that they seem reasonable or inevitable. For example, in a critical study of information systems development practices in developing countries, Avgerou (2000), noting the heavy influence of Western rationalities, concluded that information systems practices and research are often privy to a capitalist, techno-scientific view that "assumes that technology is deployed in the context of an enterprise striving for competitiveness in a free market economy." Escobar (1995) observed a systematic adherence to free market rationality in third world development projects since the 1940s. This mentality, coupled with stubborn confidence in scientific methods and technology, routinely constrained what courses of action were considered useful and possible. Escobar noted that these development conventions constituted a discourse--"a space of thought and action within which only certain things can be said, done, or imagined" (Escobar cited in Avgerou 2000). Discourse shapes our thinking in every context and domain - from the paradigms of social inquiry, to reporting styles in news media, to what qualities merit the distinction of art (Fairclough 1995; Mauws 2000; van Dijk 1996).

Discursive hegemony refers to a state in which a dominant discourse goes uncontested, assuming the weight of common sense. Recipients who neglect to question such a discourse tend to accept its dictates as fact, as their socially constructed nature becomes obscured (Fairclough 1995). Meanwhile, alternative discourses and, perhaps 
worse, the very liberty to select a favorable discourse from among multiple options become foregone considerations and the dominant view persists, safe from scrutiny. Discourse is inherently associated with power and, as with other valued social resources (e.g., money, work, status), exclusive access to discourse confers an edge in wielding respect, influence, and control (van Dijk 1996). The ability to manipulate structures of text and talk, thus achieving influence over recipients' knowledge, attitudes, and mental models, is a subtle instrument for advancing one's own agenda. Herman and Chomsky (1988) call this kind of manipulation "manufacturing the consent" of others.

\subsection{Discourse and the Social Sciences: The Problem with Neutrality}

Social scientists often set out seeking knowledge that is neutral, unbiased, objective, and value-free. Such intentions seem a stretch, however, when we note that the language, conventions, and instruments of every such inquiry are all socially constructed. Much as the researcher may strive to contribute unbiased parcels of insight to a body of knowledge that is equally pure, the fact is that strands of discourse will always inform his or her inquiries, approaches, and lines of reasoning. The potential downfall of social science is by no means the sacrifice of neutrality. Rather, it is the obfuscation of their socially constructed, non-neutral character that would undermine social studies. We can learn valuable things from openly subjective modes of inquiry, but it is crucial first to understand the values-laden, contextualized nature of our scholarly output (Yapa 1996).

Objects of social science do not have naively given properties that are just there to be described by social scientists. One convention that faultily encourages this assumption is the tacit delineation of a subject-object binary, whereby "the social-science investigator (the subject) stands outside the object employing a neutral discourse that studies the object" (Yapa 1996). Yet these perceived counterparts are, in fact, mutually constituted and inseparably linked in the space of the discourse. Failure to recognize the role of discourse in scientific inquiry makes researchers unwittingly compliant with dominant ways of thinking-and whatever stock remedies the discourse prescribes. Such compliance is particularly troubling because research is widely regarded as an important source of novel ideas.

Our analysis has two aims: (1) to grasp how a dominant economic development discourse informs academic research on inner city poverty; and (2) to understand the links between this economic development discourse and the digital divide. As we have adopted a critical stance, our discussion then proceeds to highlight why such a discursive hegemony among scholars is worrisome, and to explain why we are troubled by a tight coupling of the economic development and digital divide discourses. Finally, in light of our findings, we offer an alternative discourse for understanding the digital divide.

\subsection{Methodology}

Critical Discourse Analysis (CDA): Academic Research Publications. Widely esteemed as subject experts, academics hold unmatched access to research and its constituent discourses such as economic development and the digital divide. It should 
be instructive, therefore, to examine research journals - an important venue for scholarly reporting and discussion--as telling records of favored discourse among researchers. Our analysis takes up seven academic publications that address economic distress in American inner cities, including a work that has ascended to prominence in the field (Porter 1995); various responses to that work; and additional studies that offer distinct perspectives and approaches to inner city poverty.

Fairclough's Three-Level CDA Framework and Thompson's Discursive Types. Fairclough (1995) observed that texts constitute a major source of evidence for grounding claims about social structures, relations, and processes. Although connections between language use and the exercise of power are generally invisible, he maintains that close examinations of speech and writing can bring to light concealed mechanisms of domination.

In his three-level CDA framework, Fairclough positions discursive practice as the mediating layer between works of micro-level text production and macro-level sociocultural practice. The mediating processes of text production channel macro-level structures (e.g., ideologies, power relations) down into the micro-level text, leaving traces in the rendered product. Markings in the text, then, reproduce and reinforce their macro-level influences. The interpretive process extracts underlying meanings by probing these textual cues. CDA is critical for exposing connections between microlevel texts and macro-level power structures.

In Fairclough's framework, an order of discourse is defined by certain discursive practices associated with an institutionalized set of ideas (e.g., Third World development, inner city poverty) and the relations between them. Discursive types are thematic constructs that are vertically identifiable with a particular order of discourse. Thompson (2002), for example, identified technocracy, corporatism, and technological optimism as recurring discursive types in the World Bank's development order of discourse. ${ }^{3}$

Our approach was heavily informed by Thompson's analysis of a speech by former World Bank president James D. Wolfensohn, addressed to a Cambridge University audience in 2000 (see Table 1). Using Thompson's set of discursive types as a sensitizing framework, we roughly reverse his ground-up interpretation process (see Table 2 for an example). Rather than identify constructs anew from our readings of these texts, we began by considering how Thompson's constructs compare to studies of inner city poverty in the United States Where we recognize similar lines of reasoning and argument, we note the parallels (see Table 3); where the ideas of a particular paper strain the given template, we add new constructs (e.g., social capital, local needs), in a sense growing the original space of discourse.

\footnotetext{
${ }^{3}$ Another concept in Fairclough, speech genre refers generically to a style of language use, as employed horizontally across various orders of discourse, to achieve a certain response-e.g., interview, humor, persuasion (Thompson 2002). Because the style conventions of academic writing often discourage their (overt, liberal) use, we do not examine speech genres in this analysis.
} 
Table 1. Discursive types (adapted from Thompson 2002)

\begin{tabular}{|l|l|}
\hline \multicolumn{1}{|c|}{ Discursive Type } & \multicolumn{1}{c|}{ Description } \\
\hline Technocracy & Assertion of expertise. \\
\hline Legitimacy & Appeal to a higher order need for intervention. \\
\hline Neutrality & $\begin{array}{l}\text { Projecting ICT as a neutral force in development; } \\
\text { unproblematic neutrality, projecting status as independent . } \\
\text { We take the term as regards the way of thinking and } \\
\text { strategies/ideas advocated (i.e., discourse itself) }\end{array}$ \\
\hline Corporatism & $\begin{array}{l}\text { The deployment, hence ownership of elements of dominant } \\
\text { corporate discourse, such as leveraging, empowering, } \\
\text { objectives, and knowledge. }\end{array}$ \\
\hline $\begin{array}{l}\text { Tech(nological) } \\
\text { optimism }\end{array}$ & $\begin{array}{l}\text { The unproblematic linking of ICT to opportunity; bordering } \\
\text { on determinism. } \\
\text { Technology here refers to mainstream economic models and } \\
\text { associated notions. }\end{array}$ \\
\hline Pragmatism & $\begin{array}{l}\text { Show of ICT pragmatic use on the ground, thus ensuring } \\
\text { results. } \\
\text { In place of ICT specifically, we consider any technology, } \\
\text { strategy, or idea whose demonstrated utility is cited }\end{array}$ \\
\hline
\end{tabular}

Table 2. Comparison of CDA Notes: Thompson's Discursive Types

\begin{tabular}{|l|l|}
\hline Discursive Type & \multicolumn{1}{|c|}{ CDA Notes* } \\
\hline Technocracy & $\begin{array}{l}\text { Asserts private sector expertise; thus, firms must lead } \\
\text { revitalization of inner cities. }\end{array}$ \\
\hline Legitimacy & $\begin{array}{l}\text { Economic distress of U.S. Inner cities are perhaps the most } \\
\text { pressing issue facing the nation. }\end{array}$ \\
\hline Neutrality & $\begin{array}{l}\text { (1) Inner cities should be subject to same economic principles } \\
\text { as are other areas. } \\
\text { (2) } \begin{array}{l}\text { Rules of marketplace assume weight of law-charity } \\
\text { distorts these forces. }\end{array}\end{array}$ \\
\hline Corporatism & $\begin{array}{l}\text { Inner cities must aspire to find competitive advantage; exploit } \\
\text { market opportunities. }\end{array}$ \\
\hline optimism & $\begin{array}{l}\text { Once private sector firms are allowed to take over, inner city } \\
\text { revitalization will have genuine momentum. }\end{array}$ \\
\hline Pragmatism & $\begin{array}{l}\text { Inner cities need a radically different approach after years of } \\
\text { failed social models. }\end{array}$ \\
\hline
\end{tabular}

*From M. Porter, "The Competitive Advantage of the Inner City," Harvard Business Review, May-June 1995. 


\subsection{CDA: Discussion/Implications}

Although space constraints do not permit a full discussion here, our analysis of academic publications highlighted two important concerns. First, much of academic research omits explicit considerations of the role of discourse - and, hence, theory, research questions and responsive actions - in its studies of inner city poverty. A neutrality discourse, as described by Yapa (1996), continues to obscure the socially constructed nature of research, while automatically consigning knowledge, resources, and agency to the realm of scholars, private sector firms, and government bodies. Meanwhile the object-economic have-nots--is implicated as the needy other in need of development, the embodiment of a problem, examined and done-to, holding no insight or agency. But if subject, object, and discourse are mutually constituted and inextricably linked, such a distinction is impossibly distorted. Moreover, this discursive practice sanctions a highly unbalanced distribution of authority and wherewithal that empowers the subject while stifling the object.

Second, we found that many of Thompson's discursive types are prominently echoed in a majority of texts that address inner city economic distress. While a few papers did expand significantly on this space of discourse informed by corporatism, technocracy, neutrality, etc., much of the debate languishes within those boundaries described by Thompson.

\section{LINKING ECONOMIC DEVELOPMENT AND THE DIGITAL DIVIDE THROUGH DISCOURSE}

In this section, we examine more closely the linkages between the economic development and digital divide discourses, and how these discourses similarly seek to manufacture the consent of others. These linkages are presented in Table 3, and will be discussed in turn.

\subsection{Alleged Motivation: Equality}

Gillis and Mitchell (2002), focusing on persistent deprivation within the have-not sector, link uneven ICT access with social exclusion. They argue for bridging the divide against a regrettable scenario of unrealized potential economic and human development which cannot be excused. On an individual basis, this forgone development activity translates into higher rates of poverty, poorer health, lower literacy and quality of life than is necessary. Thus, an aptitude with ICT has become not merely useful, but more or less requisite, for effective democratic participation and economic development. Similarly, Fors and Moreno (2002) write that in our contemporary world, having access to information and knowledge plays a crucial role in advancing economic and social well-being. With the growing prevalence of ICT in prominent domains such as business, education, and government, these technologies are no longer the edge that confers an advantage to the savvy specialist. ICT competence is acquiring the status of a basic commodity that must be in place before any meaningful or productive activity can occur (Kvasny and Truex 2001). 
Table 3. Comparison of Discourses: Economic Development and the Digital Divide

\begin{tabular}{|c|c|c|}
\hline $\begin{array}{l}\text { Aspect of } \\
\text { Discourse }\end{array}$ & Economic Development & Digital Divide \\
\hline $\begin{array}{l}\text { Alleged } \\
\text { Motivation: } \\
\text { Equality }\end{array}$ & $\begin{array}{l}\text { Eradication of poverty in inner } \\
\text { cities }\end{array}$ & $\begin{array}{l}\text { Bridging the divide, i.e., } \\
\text { universal connectivity }\end{array}$ \\
\hline $\begin{array}{l}\text { Framing the } \\
\text { Problem Space }\end{array}$ & $\begin{array}{l}\text { - Statistical construction of a } \\
\text { poverty sector based on } \\
\text { income } \\
\text { - Correlation with factors } \\
\text { such as race, educational } \\
\text { attainment, unemployment, } \\
\text { dysfunctional social } \\
\text { behaviors }\end{array}$ & $\begin{array}{l}\text { - Statistical construction of } \\
\text { have/have-not sectors based } \\
\text { on access } \\
\text { - Correlation with factors such } \\
\text { as race, age, gender, income, } \\
\text { educational attainment, } \\
\text { employment, location }\end{array}$ \\
\hline $\begin{array}{l}\text { Informing } \\
\text { Questions }\end{array}$ & $\begin{array}{l}\text { How to inject money, jobs, } \\
\text { corporate investment into poor } \\
\text { areas }\end{array}$ & $\begin{array}{l}\text { How to supply hardware, } \\
\text { connections to those who lack } \\
\text { access }\end{array}$ \\
\hline $\begin{array}{l}\text { Measure of } \\
\text { Problem/ } \\
\text { Progress }\end{array}$ & $\begin{array}{l}\text { Figures for median income, } \\
\text { unemployment, educational } \\
\text { attainment, home ownership }\end{array}$ & $\begin{array}{l}\text { - Statistics profiling ICT } \\
\text { access (computer ownership, } \\
\text { Internet connectivity), and } \\
\text { usage } \\
\text { - Global divide: national e- } \\
\text { readiness assessments; } \\
\text { counted tallies of phone lines, } \\
\text { servers, web sites, etc. }\end{array}$ \\
\hline $\begin{array}{l}\text { Favored Policy } \\
\text { Strategies }\end{array}$ & $\begin{array}{l}\text { Court private sector firms; } \\
\text { increase investment, create job } \\
\text { opportunities }\end{array}$ & $\begin{array}{l}\text { Establish public access centers; } \\
\text { equip schools, libraries }\end{array}$ \\
\hline $\begin{array}{l}\text { Authors of } \\
\text { Discourse } \\
\text { (subject- } \\
\text { object) }\end{array}$ & $\begin{array}{l}\text { Government (Census Bureau); } \\
\text { private sector; international } \\
\text { aid organizations (UN } \\
\text { Development, World Bank); } \\
\text { academic research }\end{array}$ & $\begin{array}{l}\text { Government (NTIA); private } \\
\text { sector; international aid } \\
\text { organizations (DOT Force } \\
\text { [G8], UN, World Bank); NGOs } \\
\text { (Pew Internet, DD Network, } \\
\text { bridges.org); academic } \\
\text { research }\end{array}$ \\
\hline
\end{tabular}

The digital divide pretends to be a problem of inequality - an access gap that separates information haves from Internet-deprived have-nots. The digital divide rapidly ascended to high-priority status in the agenda of national governments, nonprofit groups, and international development organizations (e.g., bridges.org 2001; NTIA 2004; World Bank 2001). In support of efforts to bridge the divide, it is commonly argued that the economic, political and social well-being of all groups is contingent on access to ICT (e.g., Fors and Moreno 2002; Gillis and Mitchell 2002; NTIA 2004). Lack of access to ICT raises all manner of alarms: opportunities in the new economy are at stake; 
participation in modern democracy will require a mastery of ICT (Klein 1999; Yu 2002); untold educational benefits are lost without them (NTIA 2004). The obvious solution, by this understanding, is to furnish access to those who lack it. By connecting disadvantaged groups to ICT, we are extending to them the leading edge of innovation, the means to succeed in the new economy. With ICT access representing limitless resources and opportunity, underserved Americans can be molded by rhetoric into new markets, and positioned for empowerment in the digital age (Kvasny and Truex 2001). Thus, digital divide discourse claims legitimacy by its blameless will to level the playing field, and apparent promises to erase the inequities that have long stood in the way of underserved groups.

Similarly, economic development pretends equality because it strives to wipe out economic disparities. Porter (1995) called the crushing cycles of poverty, drug abuse, and crime one of the most pressing issues facing the nation. Bates (1997) referred to disinvestment in inner cities as a symptom of America's urban racial crisis. LoukaitouSideris (2000) painted an image of inner city strips so broken and desperate that no one could have questioned the need for responsive action. We are made to believe that these many complex ills are symptomatic of inequality-namely, that of economic wealth. Hence, the strategies of injecting wealth, private sector influence, and jobs into areas that lack them seem straightforward. It is a discourse that emphasizes poverty-a lack of money - as the heart of the problem, and urges catching up as the response.

\subsection{Framing the Problem Space, Informing Questions, Measuring Progress, and Favored Solutions}

In the economic development discourse premised on economic inequality, have/have-not dichotomies are devised through the statistical construction of a poverty sector - typically that set of households whose earnings fall short of a designated income threshold. In this way, a lack of money is the implied emergency, which begs the question, how can people increase their earnings? This statistical construct reinforces an already assumed subject-object binary, and becomes central in the formulation of strategies for understanding and addressing the problem of poverty.

The official approach to alleviating poverty consists of three steps: first, data are collected on the extent and geographical location of poverty; second, information is gathered on "causative" variables such as race, gender, and employment that may be correlated with poverty; third, information on the incidence of poverty and correlated variables is used in models to help formulate appropriate policy and action. (Yapa 1996, p. 712)

Although Yapa was writing about third world poverty and development in a global context, many of these same approaches have been applied similarly to economic development in America. Instruments such as the U.S. Census report have become standard tools for assessing the extent of poverty in the United States.

Initial studies of the digital divide proceeded similarly in the statistical profiling of a technology-deprived have-not sector. As households are considered economically 
poor for failing to make an official threshold income, individuals are singled out as information-poor if they do not make use of online content, or lack access to an Internet connection.

Statistical profiling is also routinely used to measure progress both at a national and global level. The increasingly worldwide participation of countries in campaigns to bridge the digital divide has led to a barrage of statistical studies whose findings ultimately pit each nation against all others in comparative ICT ratings (much the way nations are ranked economically by GDP, export volumes, etc.). In this context of global competition, access rankings often spur the perverse, short-sighted pursuit of leading statistics. In a 2004 address to the U.S. Department of Commerce, the U.S. President expressed his disappointment in the nation's current tenth place ranking in broadband connectivity worldwide (White House 2004). "That's not good enough," Bush protested, "We don't like to be ranked tenth in anything. The goal is to be ranked first when it comes to per capita use of broadband technology. It's in our nation's interest. It's good for our economy."

Modern development paradigms endorsed by high-profile organizations such as the United Nations and the World Bank now consistently feature e-readiness as a cornerstone of national economic development capacity (bridges.org 2001; Thompson 2002; World Bank 2001. As Thompson pointed out, the two discourses are becoming more and more inseparable, with campaigns to bridge the digital divide aligning their aims with those of economic development. Economic development is rarely contested as the dominant solution to poverty-where poverty implies a root problem of savage deficits and deep social inequities. As ICTs are positioned as key to combating deprivation, even as they otherwise introduce another aspect of lack, this whole discursive package of economic development and bridging the digital divide becomes doubly infused with the legitimacy associated with the pursuit of social equality (Thompson 2002).

\subsection{Authoring Discourse (Subject-Object)}

Yapa (1996) points out that the study of economics is premised on a situation of scarcity, in which supposedly unlimited wants encounter an inevitably limited stock of resources. Hence the problem: How do we allocate scarce resources in the most equitable, beneficial way, across these endless wants? Since capitalist economies thrive while demand is strong, and while the powers of production command supply, a certain way to stoke the economy is to keep up the endless construction of need. The wealthy, generally beyond the concerns of material subsistence already, must be induced to tap into their surpluses for novel or status/luxury goods. The growth of the economy is largely based upon the inducement of new cravings that spur and magnify consumption. In turn, manufactured wants among the wealthy spread the appeal of status and novelty, via discourse, to the broader population who, though they may be ill-equipped to afford (and in little actual need of) them, are made to believe that they must likewise seek these same goods in order to catch up. Newer, more modern lifestyles are continually invented and marketed while existing ways are phased out as obsolete and inadequate.

Recalling van Dijk (1996), access to discourse is a form of power that can amount to control over the public mind. The information wealthy exercise nearly exclusive 
command over the production and evolution of ICT; thus, they hold charge of its marketing as well. That is, information haves monopolize ICT discourse in addition to technological innovation. As the leading experts of these technologies, they establish precedents, and determine and market, via discourse, what products and standards are desirable, effective, and up-to-date. Moss (2002) highlights need formation as an important component of what he calls influence. Such influence is especially pronounced in top-down development models, in which external specialists define the needs of disadvantaged societies and individuals, whose own self-determination is thereby greatly reduced. Essentially, Moss' concept of need formation is an element of discourse, and influence here is allocated in line with a subject-object binary that privileges the expertise of the wealthy/developed to envision what the marginalized must become.

As long as the lot of the wealthy is accepted as the standard vision of prosperity, genuine equality will remain unattainable. The seemingly higher-order imperative to strive for equality is actually a prescription for permanent inequality because its terms are defined and imposed by the wealthy and powerful, who control access to the dominant discourse. By extolling their own ideals as what the marginalized must become, subjects lock their objects into an endless race to catch up while they remain ahead themselves, continually raising the bar (Kvasny and Truex 2001). As first movers, proponents of bridging the divide continue to pioneer new uses for ICT, and gain exponential benefits from their unmatched command of these technologies. Meanwhile, newcomers must contend with the pains of basic adoption, with no control over what standards and architecture have been laid in place by first movers (bridges.org 2001; Yu 2002). True digital equality will demand that newcomers not only gain access to ICT, but also become content producers and designers, exercising creativity at the forefront of innovation and discourse (Gurstein 2003).

\section{MOVING BEYOND CATCHING UP}

Having discussed the limitations of the existing discourse, and possible ways to revise it, we now begin to propose a more hopeful alternative - one that privileges the needs and resources of poor communities. The mainstream discourses that currently define economic development and the digital divide hold out predetermined notions of success to the underserved, urging them to catch up. Bent on the pursuit of a singular course of action-toward official prosperity, toward universal connectivity-these models crowd out other ways of thinking that would allow marginalized groups to pursue alternate strategies for addressing their needs. The abstract ends of eradicating poverty and, now, bridging the digital divide may have merit, but they bind people to a stock set of solutions that appease an imposed vision; such solutions lack the flexibility to take advantage of particular resources and knowledge which new users may hold. Nor have these stock fixes been shown to accomplish constructive, lasting change (e.g., Lazarus and Mora 2000).

However, we can revise the problem of inequality (with its futile logic of catching up) into more pragmatic, substantive questions of how people can meet their needs. Internet access per se is no remedy for our most pressing social problems, such as poor 
Table 4. Alternative Discourses

\begin{tabular}{|l|l|}
\hline Discursive Type & \multicolumn{1}{c|}{ Alternative Discourse* } \\
\hline Technocracy & $\begin{array}{l}\text { Authors do not assert own expertise; do not privilege expertise } \\
\text { of outside specialists in creating development framework }\end{array}$ \\
\hline Legitimacy & $\begin{array}{l}\text { Detailed profile of official poverty area demands attention; } \\
\text { local community involvement gives legitimacy to research } \\
\text { projects }\end{array}$ \\
\hline Neutrality & $\begin{array}{l}\text { Not a concern of authors to appear neutral; positions clearly } \\
\text { stated as such, theories constructed rather than asserted as fact }\end{array}$ \\
\hline Corporatism & $\begin{array}{l}\text { Authors reject mainstream corporate discourse, citing examples } \\
\text { of its failure to help Belmont (e.g., funding shortages stalled } \\
\text { development efforts) }\end{array}$ \\
\hline $\begin{array}{l}\text { Technological } \\
\text { optimism }\end{array}$ & $\begin{array}{l}\text { Argue against notion that economics/IT alone will improve } \\
\text { inner city situation }\end{array}$ \\
\hline Pragmatism & $\begin{array}{l}\text { Projects shaped by substantive questions based on concrete } \\
\text { needs; utilize available resources }\end{array}$ \\
\hline
\end{tabular}

*From L. Kvasny and L. Yapa, "Rethinking Urban Poverty: Forms of Capital, Information Technology, and Enterprise Management," Handbook of Information Systems Research: Critical Perspectives on Information Systems Design and Use, 2005.

public school systems, high unemployment, poor nutrition, and ill health (Kvasny and Sawyer 2002). But perhaps ICTs can support novel strategies for helping underserved Americans address their needs. As an instructive starting point, we revisit our discourse analysis - this time considering those insights that strained and rejected the economic development model (Table 4).

\subsection{Sketching an Alternative Discourse}

Kvasny and Yapa (2005) suggest that a lack of economic capital need not stop the underserved from seeking alternative strategies for meeting their needs. They draw ideas from Bourdieu's theory of capital, which maintains that social and cultural assets are forms of capital that, like money (economic capital), are of value in business and community building. Moreover, these three forms of capital are convertible, so there is no way to privilege any certain one. Loukaitou-Sideris (2000) and Harrison and Glasmeier (1997) likewise affirmed that tremendous business advantage often flows from intangible social capital. These authors recognized how certain groups were able to accomplish much more when empowered by professional network connections and collective action. Addressing tangible, locally determined needs can give meaning to the abstract challenges labeled as economic development and bridging the digital divide. Context helps to shift the main challenge away from making income or gaining access to ICT, to addressing particular, concrete needs. Moreover, in focusing on local communities, their unique assets and histories invite consideration, possibly offering rich resources and knowledge to the search for new solutions. 
Gurstein (2003) reflected that, where there have been useful ends to accomplish with ICT, people have sought out ways to gain access. This time, access itself is not the aim. Instead, we consider needs first, and explore how access to ICT can help in the pursuit of economic development with the following example.

Loukaitou-Sideris reported that merchants in inner city Los Angeles struggled in lackluster local sales, generally scraping by on meager profits. Similar struggles characterize retail efforts in inner city neighborhoods of West Philadelphia (Kvasny and Yapa 2005). Customers in the immediate geographic area have little collective buying power, while more affluent residents who drive down the business corridor, deterred by safety concerns, habitually do not stop to shop. The physical environment is no longer inviting due to criminal activity, unattractive storefronts which have fallen into disrepair, rubble strewn vacant lots, and abandoned structures interspersed among the active businesses. Can the Internet be of service to struggling small businesses in such a setting? What if these merchants could peddle their goods to a much broader customer base online? If their market of possible buyers spanned the entire Internet user community rather than just a few miles' radius, then merchants might well enjoy increased sales, especially if many of those online shoppers could better afford to purchase their goods, while also acquiring meaningful ICT skills and business acumen.

A number of small business owners in West Philadelphia have learned how to magnify their sales volumes by seeking far larger markets. A local eBay specialist there has instructed small business owners on how to use the Web's largest auction site to advertise their products to a worldwide audience. Especially for small businesses in rural or inner city communities, the advantages of increased visibility and removed geographical boundaries may vastly improve sales where the local market is limited.

\subsection{Conclusion}

Our analysis in the preceding sections examined the often unseen influence of discourse in academic conversations about economic development and the digital divide. In failing to contend with institutional discursive practices, social science researchers effectively abandon creativity for one dominant model, whereby economic and technological determinism constrain all solutions to the set of profit-maximizing transactions. Such strategies are objectionable because they have yet to prove themselves tractable or effective. Moreover, these solutions place the greater part of ability and material means in the domain of scholars, private sector firms, and government, leaving underserved groups - whose lives are the most affected by this discussion-with stiflingly little agency.

Where subjects do come to gain a knowing awareness of discourse, they maintain a clarity and command over the questions, theories, and research designs that both constrain learning and are the means to push it further. If we are mindful of the many perspectives, ideologies, and techniques that shape research and knowledge, and critically examine their effects, then we can regard situations with improved clarity and flexibility, while retaining access to a fertile host of alternative views and possibilities. 


\section{Acknowledgements}

This material is based upon work supported by the National Science Foundation under Grant No. 0238009. Any opinions, findings, and conclusions or recommendations expressed in this material are those of the authors and do not necessarily reflect the views of the National Science Foundation.

\section{References}

Avgerou, C. "Recognising Alternative Rationalities in the Deployment of Information System," Electronic Journal of Information Systems in Developing Countries (3:7), 2000, pp. 1-15. (available online at http://www.ejisdc.org/ojs/).

Bates, T. "Response: Michael Porter's Conservative Urban Agenda Will Not Revitalize America's Inner Cities: What Will?," Economic Development Quarterly (11:1), 1997, pp. $39-44$.

bridges.org. "Spanning the Digital Divide: Understanding and Tackling the Issues," May 2001 (available online at http://www.bridges.org/spanning/index.html).

Fairclough, N. Critical Discourse Analysis: The Critical Study of Language, Harlow, England: Pearson Education Limited, 1995.

Escobar, A. Encountering Development: The Making and Unmaking of the Third World, Princeton, NJ: Princeton University Press, 1995.

Fors, M., and Moreno, A. "The Benefits and Obstacles of Implementing ICT Strategies for Development from a Bottom-Up Approach," Aslib Proceedings (54:3), 2002, pp. 198-206.

Foucault, M. The Politics of Truth, Cambridge, MA: Semiotext(e) (MIT Press), 1997.

Gillis, B., and Mitchell, M. "Can ICT Stimulate Economic Development?" Digital Divide Network, August 2002 (available online at http://www.digitaldividenetwork.org).

Gurstein, M. "Effective Use: A Community Informatics Strategy Beyond the Digital Divide," First Monday (8:12), 2003, (available online at http://firstmonday.org/issues/issue8_12/ gurstein/index.html).

Harrison, B., and Glasmeier, A. "Response: Why Business Alone Won't Redevelop the Inner City: A Friendly Critique of Michael Porter's Approach to Urban Revitalization," Economic Development Quarterly (11:1), 1997, pp. p. 28-38.

Herman, E., and Chomsky, N. Manufacturing Consent, New York: Pantheon Books, 1988.

Klein, H. K. "Tocqueville in Cyberspace: Using the Internet for Citizen Associations," The Information Society (15), 1999, pp. 213-220.

Kvasny, L., and Sawyer, S. "Reproduction of Inequality through Information Technology," Proceedings of the Shaping the Network Society Symposium, Seattle, Washington, May 5-8, 2002, pp. 170-174.

Kvasny, L., and Truex, D. "Defining Away the Digital Divide: A Content Analysis of Institutional Influences on Popular Representations of Technology," in N. Russo, B. Fitzgerald, and J. I. DeGross (eds.), Realigning Research and Practice in IS Development: The Social and Organizational Perspective, Boston: Kluwer Academic Publishers, 2001, pp. 399-414.

Kvasny, L., and Yapa, L. "Rethinking Urban Poverty: Forms of Capital, Information Technology, and Enterprise Development," in D. Howcroft and E. Trauth (eds.), Handbook of Information Systems Research: Critical Perspectives on Information Systems Design, Implementation and Use, London: Kluwer, 2005, pp. 350-364.

Lazarus, W., and Mora, F. "Online Content for Low-Income and Underserved Americans: The Digital Divide's New Frontier," The Children's Partnership, Santa Monica, CA, 2000 (available online from http://www.childrenspartnership.org/). 
Loukaitou-Sideris, A. "Revisiting Inner-City Strips: A Framework for Community and Economic Development," Economic Development Quarterly (14:2), 2000, pp. 165-181.

Mauws, M. "But Is it Art? Decision Making and Discursive Resources in the Field of Cultural Production," Journal of Applied Behavioral Science (36:2), 2000, pp. 229-244.

Moss, J. "Power and the Digital Divide," Ethics and Information Technology (4), 2002, pp. 159 165 .

NTIA. "A Nation Online: Entering the Broadband Age, National Telecommunications and Information Administration," U.S. Department of Commerce, Washington, DC, 2004 (available online at http:/www.ntia.doc.gov/reports/anol/NationOnlineBroadband04.htm).

Porter, M. "The Competitive Advantage of the Inner City," Harvard Business Review (73:3), 1995, pp. 55-71.

Thompson, M. "ICT, Power, and Developmental Discourse: A Critical Analysis," in E. Wynne, E. Whitley, M. Myers, and J. I. DeGross (eds.), Global and Organizational Discourse About Information Technology, Boston: Kluwer Academic Publishers, 2002, pp. 347-374.

van Dijk, T. A. "Discourse, Power and Access," in C. R. Caldas-Coulthard and M. Coulthard (eds.), Texts and Practices: Readings in Critical Discourse Analysis, London: Routledge, 1996, pp. 84-106.

White House. "President Bush: High Tech Improving Economy, Health Care, Education," U. S. Department of Commerce, Washington, DC, June 24, 2004 (available online at www.whitehouse.gov/news/releases/2004/06/20040624-7.html).

World Bank. "World Development Indicators 2001," 2001 (available online at http:/ www.worldbank.org/data/wdi2001/pdfs/tab5_10.pdf).

Wynn, E., Whitley, E., Myers, M., and DeGross, J. I. (eds.). Global and Organizational Discourse About Information Technology, Boston: Kluwer Academic Publishers, 2002.

Yapa, L. "What Causes Poverty? A Postmodern View," Annals of the Association of American Geographers (86:4), 1996, pp. 707-728.

Yu, P. K. "Bridging the Digital Divide: Equality in the Information Age," Cardozo Arts \& Entertainment Law Journal (20:1), 2002, pp. 1-52.

\section{About the Authors}

Leslie Tu holds a BS in classic studies from Wellesley College. She earned an MS in Information Sciences and Technology at the Pennsylvania State University. Her research examines language and information technology. Leslie can be reached at lct109@psu.edu.

Lynette Kvasny is an assistant professor of Information Sciences and Technology, and a founding member of the Center for the Information Society at the Pennsylvania State University. She earned a Ph.D. in Computer Information Systems at Georgia State University. She is the recipient of the National Science Foundation's CAREER award. Her research examines historically underserved groups and their adoption and use of information technology. Her work has appeared in the Data Base for Advances in Information Systems, Journal of Computer Mediated Communication, International Journal of Technology, and Human Interaction, and Information, Communication and Society. Kvasny can be reached at lkvasny@ist.psu.edu. 